\title{
Extracellular enzyme activity in a river-bay-shelf transect: variations in polysaccharide hydrolysis rates with substrate and size class
}

\author{
S. C. Keith, C. Arnosti* \\ Dept. of Marine Sciences, CB \#3300, 12-7 Venable Hall, University of North Carolina, Chapel Hill, \\ North Carolina 27599-3300, USA
}

\begin{abstract}
The microbial remineralization of high molecular weight dissolved organic carbon (DOC) begins with extracellular enzymatic hydrolysis, since macromolecules must be hydrolyzed to produce substrates sufficiently small to cross microbial membranes. In order to investigate substrate and size-class related patterns in extracellular enzymatic activity in the water column, potential hydrolysis rates of 4 polysaccharides (xylan, laminarin, pullulan, and fucoidan) were measured at stations in the Delaware River, Bay, and shelf. Potential hydrolysis rates of xylan and laminarin varied by station and season, but xylan hydrolysis rates typically exceeded those of laminarin by factors of 2 to 10. In contrast, pullulan and fucoidan hydrolysis rates were (with a single exception for fucoidan) essentially zero for all seasons and stations. Size fractionation experiments showed that most xylan- and laminarin-hydrolyzing activity was associated with the $>0.45 \mu \mathrm{m}$ size fraction. The contribution of free dissolved enzymes (the $<0.2 \mu \mathrm{m}$ fraction), however, was at times substantial. In September, when potential activities of both enzymes were at a maximum, the free-enzyme fraction contributed 48 to $69 \%$ of the xylan-hydrolyzing activity at the freshwater and midbay stations, and nearly $100 \%$ of the laminarin-hydrolyzing activity at the midbay and plume stations. These spatial and temporal variations in the contributions of free enzymes to laminarin and xylan hydrolysis may help to explain the decoupling of measurements of specific enzyme activities from large-scale measurements of total microbial populations. The contrasting behaviors of laminarin, xylan, pullulan, and fucoidan, all of which are soluble polysaccharides, suggest that certain types of polysaccharides may resist hydrolysis by planktonic microbial extracellular enzymes and, therefore, are relatively unavailable as substrates to the planktonic community.
\end{abstract}

KEY WORDS: Extracellular enzyme $\cdot$ Polysaccharide $\cdot$ Remineralization $\cdot$ Xylanase $\cdot$ Laminarinase

\section{INTRODUCTION}

Microbial communities play a critical role in the cycling of dissolved organic carbon (DOC) (Azam 1998), which is one of the largest active organic carbon reservoirs on earth (Hedges 1992). Up to $50 \%$ of the high molecular weight (HMW) fraction of DOC consists of polysaccharides (Benner et al. 1992). Phytoplankton are likely a major source of these polysaccharides: cul-

${ }^{*}$ Corresponding author. E-mail: arnosti@email.unc.edu ture studies have shown that on average, carbohydrates constituted $66 \%$ of HMW DOC freshly produced by phytoplankton (Biersmith \& Benner 1998). Much of the DOC newly produced by phytoplankton is rapidly remineralized by bacteria (Norrman et al. 1995), but mesocosm experiments have also shown that 25 to $35 \%$ of this newly produced DOC resists microbial remineralization on timescales of at least $2.5 \mathrm{yr}$ (Fry et al. 1996). In addition, an average DOC radiocarbon age of $6000 \mathrm{yr}$ demonstrates that some fraction of DOC is resistant to microbial remineralization on timescales of ocean mixing (Williams \& Druffel 1987). 
Little is known about the factors that distinguish fractions of phytoplankton-produced DOC which are rapidly remineralized by bacteria from those which are not. The structure of HMW DOC is likely to be important because microbial remineralization of HMW DOC begins with extracellular enzymatic hydrolysis. Molecules greater than 650 Da are too large to pass through the outer membrane of bacteria (Decad \& Nikaido 1976), and must be enzymatically hydrolyzed outside the cell. The structural specificities of these extracellular enzymes, as well as the rates at which they operate, therefore critically affect the rates and means by which DOC is cycled.

Extracellular enzyme activity in aquatic systems is typically assessed by means of low molecular weight (LMW) substrate analogs such as methylumbelliferyl (MUF)- $\alpha$-glucose and MUF- $\beta$-glucose (e.g. Hoppe 1983, Smith et al. 1992, Martinez et al. 1996). Hydrolysis is measured as an increase in fluorescence upon cleavage of the MUF-monosaccharide bond. While simple to use, these substrate analogs cannot fully represent either the compositional complexity or the 3-dimensional structure of polysaccharides in solution. Furthermore, LMW substrate analogs can be hydrolyzed in the periplasm, and therefore measure some combination of extracellular + periplasmic enzyme activities (Martinez \& Azam 1993) while HMW substrates must be hydrolyzed prior to transport into the periplasm. In addition, polysaccharide-hydrolyzing enzymes typically contain distinct domains for substrate binding and cleavage (Warren 1996); substrates or substrate proxies which do not match these structural features are not likely to be hydrolyzed by the extracellular enzymes which contain these domains.

In this study, we apply a recently developed method using fluorescently labeled (FLA) polysaccharides (Arnosti 1995, 1996) to assess enzyme activities and to compare directly the potential hydrolysis rates of 4 structurally distinct polysaccharides in the water column. The 4 polysaccharides-pullulan, laminarin, xylan, and fucoidan - vary in monomer composition, anomeric linkage and linkage position, as well as molecular weight. Because polysaccharide-hydrolyzing enzymes typically are sensitive to these structural features (e.g. Antranikian 1992), distinctly different enzymes would be required to hydrolyze these substrates. These polysaccharides were chosen because all are present in marine phytoplankton, and/or activities of the enzymes that hydrolyze these polysaccharides have been demonstrated in marine bacteria. Laminarin is a storage polysaccharide produced by bacillariophytes and phaeophytes, while fucoidan is a storage polysaccharide produced by Fucus sp. and other phaeophytes (Bold 1985). Xylan is produced by vascular plants, including marsh plants, and by some rhodophytes and chlorophytes (Bold 1985). Laminarinand pullulan-hydrolyzing enzyme activity has been detected in cultures of marine bacteria (Brown et al. 1990, Davis 1992, Arnosti et al. 1994), as well as in marine sediments (Wainwright 1981, Arnosti 1996, 1998). Xylanase activity has also been measured in both marine (Boschker et al. 1995, Arnosti 1998) and freshwater (Chappell \& Goulder 1995) sediments.

The component monomers of these polysaccharides - glucose, xylose, and fucose-are all common constituents of HMW DOC (Aluwihare et al. 1997, Biersmith \& Benner 1998). Two of the very few studies on the chemical structures of dissolved carbohydrates in seawater report isolation of a HMW glucose polysaccharide with 1,4 and 1,6 linkages (a description which fits pullulan) from the North Pacific, as well as laminaribiose and laminaritriose (LMW oligomers of laminarin) from Mikawa Bay, Japan (Sakugawa \& Handa 1985, Sakugawa et al. 1985). Based on available information, therefore, the polysaccharides we selected should be reasonable representatives of some of the HMW polysaccharides available as substrates to the planktonic microbial community.

We also sought to assess the contributions of free enzymes to substrate hydrolysis, and to investigate the size-classes with which specific types of enzyme activity are associated. The extracellular enzymes which hydrolyze organic macromolecules may be attached to surfaces or free in solution. Enzyme production can be induced in response to specific environmental cues. Some bacteria are known to release enzymes into solution as a function of growth phase or substrate concentration (Antranikian et al. 1987). Free enzymes may also be present in solution due to viral lysis (Karner \& Rassoulzadegan 1995) or the effects of zooplankton grazing (Bochdansky et al. 1995). Potential hydrolysis rates of the 4 polysaccharides were measured in sizefractionated water samples. Samples were collected at 3 different time periods from the Delaware River, Bay, and coastal Atlantic Ocean to determine whether the effects of polysaccharide structure and enzyme activity among size classes vary at different times of year.

\section{MATERIALS AND METHODS}

Study site. Delaware Bay has been the site of many investigations of microbial activity and water chemistry (Sharp et al. 1982, Sharp et al. 1986, Kirchman \& Hoch 1988, Hoch \& Kirchman 1993). The bay is generally vertically well mixed and has a flushing time of 80 to $100 \mathrm{~d}$ (Ketchum 1952). DOC values in the river range from ca $360 \mu \mathrm{M}$ at the freshwater stations to ca $100 \mu \mathrm{M}$ at the bay mouth and plume, show conservative 
behavior between the freshwater stations and the bay mouth, and are relatively constant year-round (Sharp et al. 1982). We sampled 3 to 4 stations on 3 different cruises (Fig. 1, Table 1). Stns 2 (sampled in June and September) and 14 (sampled in January) are referred to as the freshwater stations. Stn 24 , the midbay station, in the middle of the lower estuary, is the site of the chlorophyll maximum during spring blooms (Kirchman \& Hoch 1988). Stns P1 (sampled in June and September) and 28 (sampled in January) are located along the southern coast, and are referred to as the plume. Stn 58 is located just past the shelf break, at $38^{\circ} 05^{\prime} \mathrm{N}$, $73^{\circ} 36^{\prime} \mathrm{W}$, with a water depth of $2000 \mathrm{~m}$.

Substrate synthesis. The polysaccharides used in this study, pullulan $(\alpha[1,6]$-linked maltotriose, molecular weight [MW] ca $200 \mathrm{kDa})$, laminarin $(\beta[1,3]$-linked glucose, MW ca $6 \mathrm{kDa})$, xylan $(\beta[1,4]$-linked xylose, MW ca $8 \mathrm{kDa}$ ), and fucoidan (sulfated $\alpha[1,4]$-linked fucose, MW ca 30 to $50 \mathrm{kDa}$ ), were obtained from

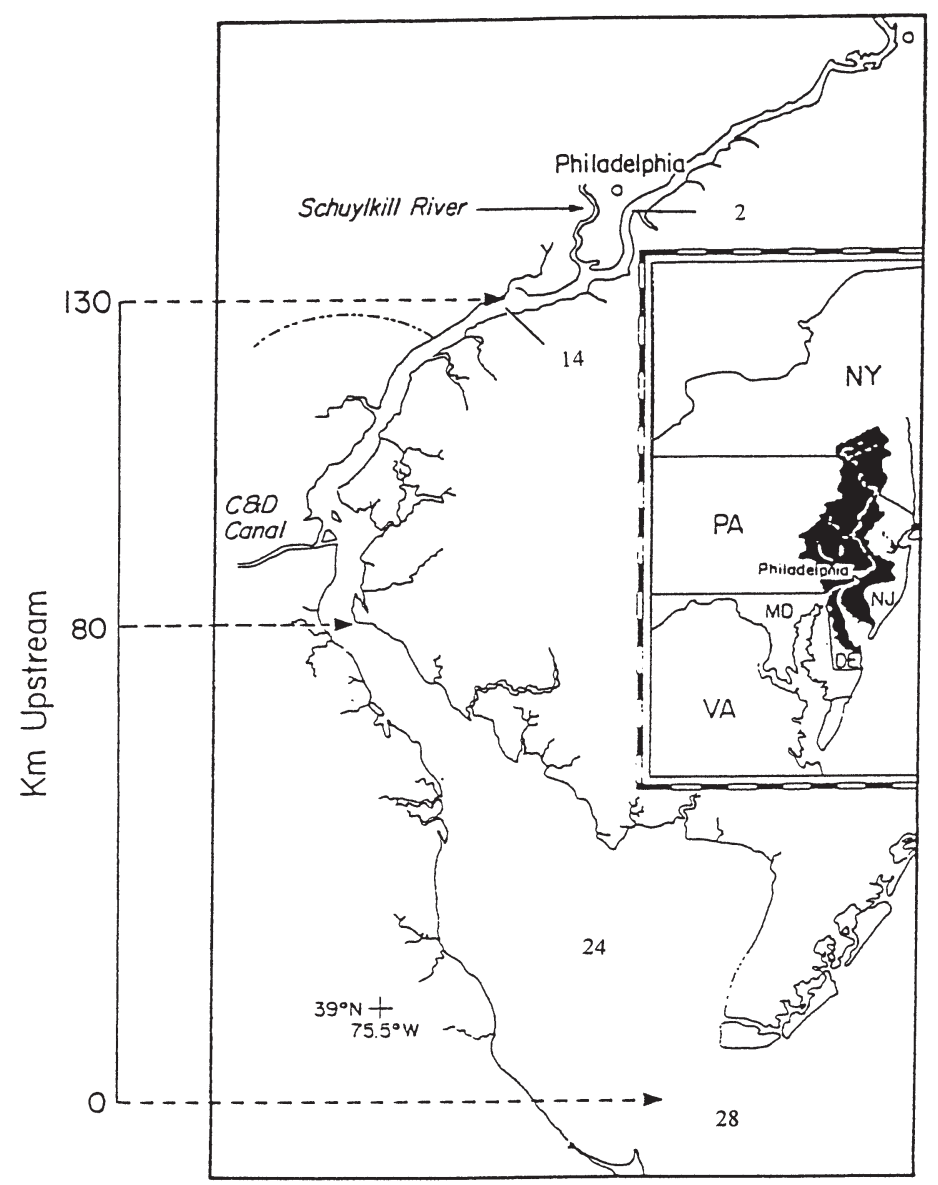

Fig. 1. Location of river/bay sampling stations $(2,14,24,28,58, \mathrm{P} 1)$ in Delaware Bay (adapted from Cifuentes et al. 1988). The plume station (Stn P1) is located ca 10 miles south of the bay mouth, 3 miles offshore. The shelf break station (Stn 58) is ca 75 miles from the bay mouth, at $38^{\circ} 05^{\prime} \mathrm{N}, 73^{\circ} 36^{\prime} \mathrm{W}$. Note: 1 mile $=1.609 \mathrm{~km}$
Table 1. Temperature (SST), salinity (S), and fluorescence (TU: Turner units) at Delaware River, Bay, plume, and shelf stations sampled in thisstudy. nd $=$ not determined

\begin{tabular}{|lccc|}
\hline Station & SST $\left({ }^{\circ} \mathrm{C}\right)$ & S (PSU) & $\begin{array}{c}\text { Fluorescence } \\
\text { (TU) }\end{array}$ \\
\hline Jun 1997 & & & \\
$\quad$ Freshwater (2) & 20.0 & 0.1 & 1585 \\
Midbay (24) & 18.4 & 20.3 & 782 \\
Plume (P1) & 15.4 & 31.1 & 500 \\
Sep 1997 & & & \\
Freshwater (2) & 21.8 & 0.1 & 581 \\
Midbay (24) & 23.1 & 24.2 & 1466 \\
Plume (P1) & 22.4 & 31.0 & 249 \\
Jan 1998 & & & \\
Freshwater (14) & 6.7 & 0.1 & 592 \\
Midbay (24) & 5.9 & 22.2 & 1352 \\
Plume (28) & 7.2 & 30 & nd \\
Shelf (58) & 15.4 & 35.5 & 214 \\
\hline
\end{tabular}

Sigma (St. Louis, MO, USA). Fluorescently labeled polysaccharides were prepared by adapting the method of Glabe et al. (1983), as described in detail in Arnosti (1996).

Sample collection and incubation. Samples were collected from freshwater, midbay, and plume stations in June 1997 ( 2 mo after the peak of the spring bloom), September 1997, and January 1998. Surface seawater from the shelf break station was also obtained in January 1998. Water samples were collected in 101 Niskin bottles from ca $2 \mathrm{~m}$ depth and transferred aboard the ship into a glass bottle, or pumped directly into a glass bottle. Shelf break water was pumped from $10 \mathrm{~m}$ depth. All glassware was cleaned, washed with distilled water prior to sampling, and rinsed 3 times with newly collected seawater. During the June 1997 cruise, the water samples for the midbay xylan incubations were taken on 2 consecutive days. Pullulan and fucoidan hydrolysis measurements were not performed at the freshwater and plume stations during the September 1997 and January 1998 cruises.

For each series of experiments, triplicate $17 \mathrm{ml}$ portions were dispensed into $20 \mathrm{ml}$ glass scintillation vials to measure total activity in unfractionated water. A set of filtration experiments was also conducted in order to determine the size fractions with which enzymatic activity was associated. Water for the filtration experiments during the June 1997 cruise was transferred to $60 \mathrm{ml}$ disposable syringes and filtered through $0.45 \mu \mathrm{m}$ pore-size sterile surfactant free cellulose acetate (SFCA) filters. Seventeen $\mathrm{ml}$ portions of this water were dispensed in a series of replicate 
vials. The remainder of the filtered water was then filtered through a $0.2 \mu \mathrm{m}$ pore-size sterile SFCA filter and dispensed into vials (note that fractionation experiments were not carried out for xylan at the freshwater and plume stations in June). For the September and January cruises, water was first filtered through a combusted GF/F filter (Whatman, $0.7 \mu \mathrm{m}$ nominal poresize) at low pressure (ca $12 \mathrm{~cm} \mathrm{Hg}$ vac.) using a Nalgene hand pump, then serially through the 0.45 and $0.2 \mu \mathrm{m}$ pore-size filters.

The relative contributions of the 0.45 to $0.2 \mu \mathrm{m}$ fraction and the $<0.2 \mu \mathrm{m}$ size fraction to total enzymatic activity were determined by comparing hydrolysis rates of these size fractions to those measured in the unfiltered water samples. Activity in the 0.45 to $0.2 \mu \mathrm{m}$ fraction was calculated by subtracting the activity measured in the (operationally defined) free enzyme fraction $(<0.2 \mu \mathrm{m})$. Relative activities of the 0.45 to $0.2 \mu \mathrm{m}$ and the free enzyme fractions were then calculated as fractions of the total activity, as measured in the unfractionated water samples. In 3 instances where calculated hydrolysis rates for the $<0.2 \mu \mathrm{m}$ fraction were apparently higher than for the 0.45 to $0.2 \mu \mathrm{m}$ fraction, the mean rates for each size class were not statistically different (Student's $t$-test, $\mathrm{p}>0.05)$.

Each substrate was added to 3 replicate vials to yield a $12 \mu \mathrm{M}$ monomer-equivalent solution, so that complete hydrolysis of each polymer would yield $12 \mu \mathrm{M}$ monosaccharides. This approach was chosen in order to be able to compare hydrolysis rates in a manner independent of the rate calculation model: if all substrates were hydrolyzed on the same relative time scales, each would be reduced to the monomer size class at the same time point. Because of initial concerns about detection limits due to low substrate fluorescence, however, fucoidan was added at a concentration of $130 \mu \mathrm{M}$ monomer-equivalent for the June and September 1997 collections.

After substrate addition, vials were capped, shaken, and stored in the dark at in situ temperatures for the duration of the study. For subsample collection, $0.7 \mathrm{ml}$ of sample was filtered through a $0.2 \mu \mathrm{m}$ pore-size nonsterile filter (SFCA) and immediately frozen until analysis. Time zero subsamples were taken immediately following completion of substrate addition for all samples at a given station. Further subsamples were taken every 1 to $2 \mathrm{~d}$ for $10 \mathrm{~d}$, and then at weekly intervals for up to $50 \mathrm{~d}$. Rates reported here are based on $6 \mathrm{~d}$ incubations.

Sample analysis and potential hydrolysis rate calculations. Size exclusion chromatography was performed using a Sephadex G-50 column $(39 \times 1 \mathrm{~cm})$. Mobile phase (100 mM NaCl, $50 \mathrm{mM} \mathrm{NaH} \mathrm{PO}_{4} /$ $\mathrm{Na}_{2} \mathrm{HPO}_{4}, \mathrm{pH} 8.0$ ) was pumped at $1.0 \mathrm{ml} \mathrm{min}{ }^{-1}$ (Shi- madzu LC-10AT pump, SCL-10A system controller, SIL-10A autoinjector), and the sample injection volume was $100 \mu \mathrm{l}$. Column outflow passed through a Hitachi L-7480 fluorescence detector (excitation: $490 \mathrm{~nm}$, emission: $530 \mathrm{~nm}$ ). Data were recorded on a Gateway 2000 PC, using Shimadzu Class-VP software. Methods for column characterization and the calculation of potential hydrolysis rates are described in detail in Arnosti (1996, 2000). Potential hydrolysis rates are reported here as $\mathrm{nM}$ monomer $\mathrm{h}^{-1}$. It should be noted that the rates reported here must be considered potential hydrolysis rates, since added substrate competes with naturally occurring substrates of unknown concentration for enzyme active sites.

Reproducibility of MW distributions from elution profiles of replicate injections of standards and samples was within ca $1 \%$, when repeated injections were made within $24 \mathrm{~h}$. Elution profiles for subsamples reanalyzed after $1 \mathrm{yr}$ of storage at $-4^{\circ} \mathrm{C}$ showed some evidence of loss of fluorescent tag from polymers, and a concurrent increase in free tag-size products. For all samples reported in this study, time zero and $6 \mathrm{~d}$ subsamples were analyzed within 1 wk of each other. Elution profiles showed that hydrolysis of xylan and laminarin first produced intermediate molecular weight products, then generated LMW products (Fig. 2). Where elution profiles of subsamples did not show that molecular weights had decreased compared to time zero profiles, rates are reported as zero.

Blanks and controls. Controls were made by addition of $34 \mu \mathrm{l}$ mercuric chloride solution $(6.25 \% \mathrm{w} / \mathrm{v})$ to a $17 \mathrm{ml}$ water sample several minutes before substrate addition. In order to check for background fluorescence, blanks (no substrates added) were included for each filtration treatment at each station. Controls and blanks were incubated and subsampled as described above. Background fluorescence of blanks was zero at excitation and emission wavelengths of 490 and $530 \mathrm{~nm}$ respectively. Control treatments indicated that no abiotic processes contributed to substrate hydrolysis in the time frame reported here. Some free tag-size products were generated, but without the production of intermediate weight products (data not shown), which is characteristic of the activity encountered with these substrates (Fig. 2). Hydrolysis rates for control treatments have not been subtracted from sample rates.

\section{RESULTS}

The most striking result was that xylan and laminarin were rapidly hydrolyzed, while pullulan and fucoidan remained essentially unhydrolyzed during the $6 \mathrm{~d}$ incubation (Fig. 2). This pattern was consistent 
even for samples monitored over longer time periods. While elution profiles from 2, 4 , and $6 \mathrm{~d}$ incubations of xylan and laminarin demonstrated progressive production of intermediate and LMW products, the situation was completely different for pullulan. There were no significant changes in pullulan elution profiles even when monitored for $50 \mathrm{~d}$ after substrate addition. Pullulan elution profiles indicated slight generation of free tag, without production of intermediate molecular weight products. The chromatogram from the June midbay station (Fig. 2) is representative of the low rise centered at $55 \mathrm{~min}$ corresponding to free tag elution. Previous studies of pullulan hydrolysis in enrichment cultures and in sediments have demonstrated production of intermediate weight polymers which are progressively hydrolyzed to lower molecular weights (Arnosti et al. 1994, Arnosti 1995, 1998). Loss of fluorescent tags from pullulan is not likely to be due to the enzymes responsible for polymer cleavage, as the structure of the isourea linkage between the FLA tag and the carbohydrate is significantly different from the glycosidic bond between carbohydrates. Because of the fundamental differences between elution profile changes observed in this study and those seen previously, enzymatic hydrolysis of pullulan is most probably absent in the samples reported here. Similarly, the elution profiles for all samples of fucoidan changed very little over the $6 \mathrm{~d}$ time course of incubation (Fig. 2). Over longer time periods, elution profiles from fucoidan-amended samples also indicated minimal hydrolysis of substrate, with one exception. A single replicate from the midbay station in September showed significant hydrolysis after $16 \mathrm{~d}$ of incubation, and nearly complete hydrolysis by $30 \mathrm{~d}$ (data not shown). Because of the absence of observable changes in pullulan and fucoidan elution profiles during the $6 \mathrm{~d}$ incubations, temporal, spatial, and size class comparisons will focus on laminarin and xylan.

Also notable were the high rates of xylan hydrolysis, which usually exceeded laminarin hydrolysis by factors of 2 to 10 . With the exception of the January midbay, plume, and shelf stations (rates of 3.8, 0.4, and $23 \mathrm{nM}$ xylose $\mathrm{h}^{-1}$, respectively), xylan hydrolysis rates ranged from 45 to $72 \mathrm{nM}$ xylose $\mathrm{h}^{-1}$ and were relatively consistent between stations and seasons (Fig. 3). For xylan, a measure of day-to-day rate consistency at a single station was obtained during the June cruise, when samples for midbay xylan hydrolysis rate mea- surements were taken on 2 consecutive days, the first time for the 4 substrate comparison, and the second time for the filtration series. Potential hydrolysis rates for unfiltered samples taken on the 2 days were $51 \pm$ 1.2 and $42 \pm 12 \mathrm{nM}$ xylose $\mathrm{h}^{-1}$, respectively. Laminarin potential hydrolysis rates were consistently lower than for xylan, covering a range of 2.4 to $40 \mathrm{nM}$ glucose $\mathrm{h}^{-1}$, and also varied more between seasons (Fig. 3).

Potential hydrolysis rates were generally higher in September than in June or January. The elevation in laminarin hydrolysis rates (an increase by a factor of 2 to 4) was particularly pronounced in September (Fig. 3). Between-station differences were most pronounced for both substrates during the January cruise. The plume station in January had the lowest rates observed for both laminarin and xylan hydrolysis $(2.4 \pm$ $0.7 \mathrm{nM}$ glucose $\mathrm{h}^{-1}$ and $0.4 \pm 0.4 \mathrm{nM}$ xylose $\mathrm{h}^{-1}$, respectively), although rates at the freshwater station in January were comparable to rates measured during other seasons (Fig. 3).

The filtration experiments clearly demonstrated that although the highest hydrolytic activity was generally observed in the $>0.45 \mu \mathrm{m}$ size fraction, the free enzyme size-fraction can at times contribute significantly to total hydrolytic activity. During the September cruise, for example, the free-enzyme size fraction $(<0.2 \mu \mathrm{m})$ contributed essentially all of the activity at the midbay and plume stations for laminarin (Fig. 4), as 

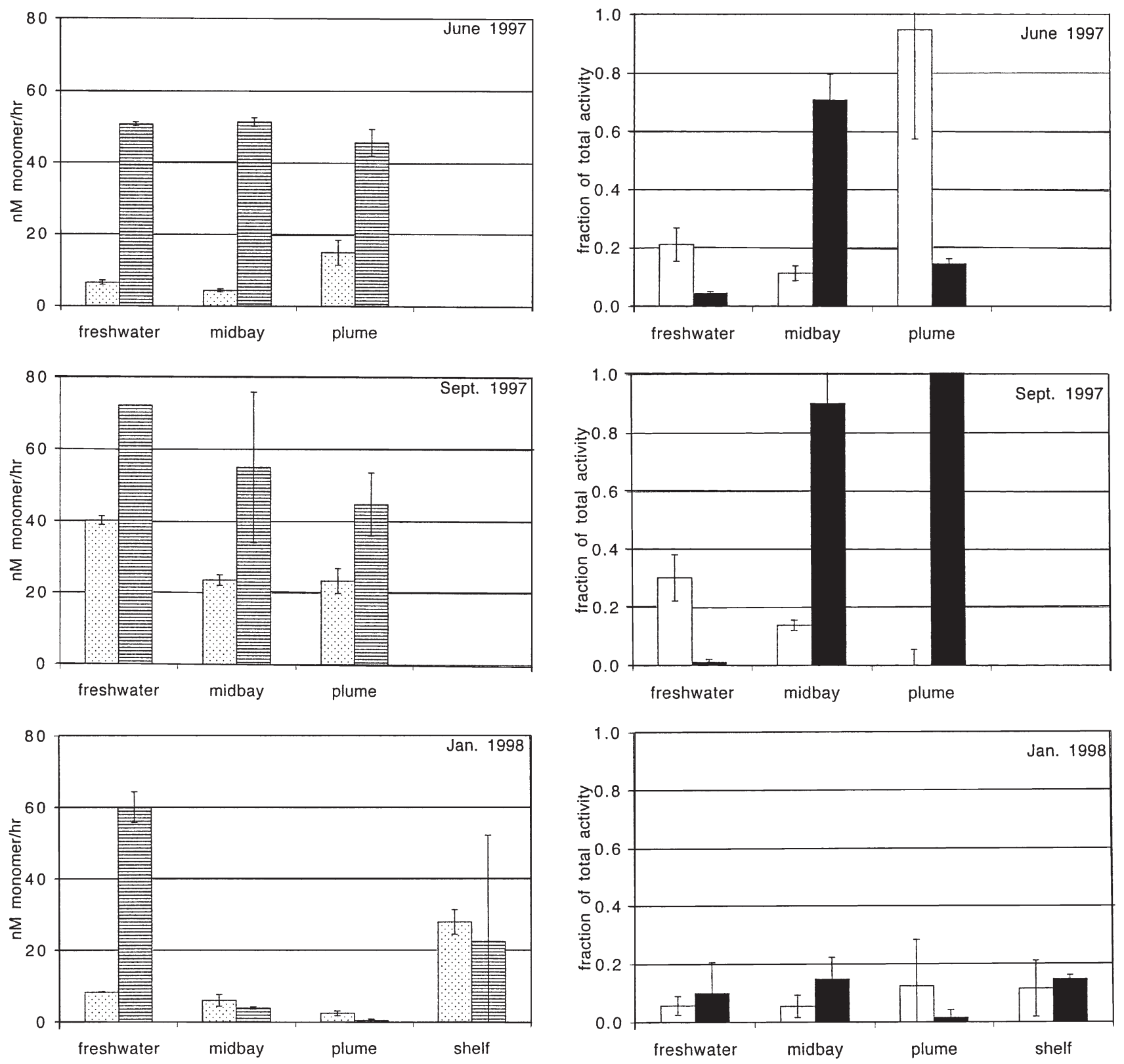

Fig. 3. Potential hydrolysis rates for unfiltered xylan and laminarin samples (6 d incubations). Spotted bars: laminarin; striped bars: xylan. Note that the shelf station was sampled only in January. Error bars represent $\pm 1 \mathrm{SD}(\mathrm{n}=3)$

well as $69 \%$ of total activity at the freshwater station and $48 \%$ of total activity at the midbay station for xylan (Fig. 5). Activity among size classes varied considerably by substrate as well as by station and cruise. The 0.45 to $0.2 \mu \mathrm{m}$ fraction contributed a sizeable percentage of total activity at specific times and locations: for xylan at the freshwater and plume stations in September (32 and $22 \%$ of total activity, respectively; Fig. 5), and for the laminarin at all 3 stations in June $(21,11$,

Fig. 4. Size-fractionation experiments (6 d incubations): laminarin hydrolysis rates as a fraction of rates measured in unfiltered samples. White bars: 0.45 to $0.2 \mu \mathrm{m}$ fraction. Black bars: free enzyme $(<0.2 \mu \mathrm{m})$ fraction. Error bars represent $\pm 1 \mathrm{SD}(\mathrm{n}=3)$

and $95 \%$, respectively), as well as for the freshwater station (30\% of total activity) in September (Fig. 4). Combined, the 0.45 to $0.2 \mu \mathrm{m}$ and the $<0.2 \mu \mathrm{m}$ fractions accounted for 25 to $100 \%$ of the total laminarinhydrolyzing activity in June and September, and 35 to $100 \%$ of the total xylan-hydrolyzing activity in September. (Note that size fractionation experiments were not performed in June for xylan at the freshwater and plume stations.) 


\section{DISCUSSION}

\section{Contrasts in potential enzyme activities}

Rapid hydrolysis of xylan and laminarin contrasts sharply with essentially zero hydrolysis of both pullulan and fucoidan over the course of the $6 \mathrm{~d}$ incubations. Even over longer incubation periods, pullulan remained unhydrolyzed, while only 1 fucoidan replicate was significantly hydrolyzed over a timescale of $1 \mathrm{mo}$. The contrast between pullulan and laminarin is particularly notable, since both are soluble linear glucose polysaccharides, differing in linkage position and anomeric linkage. Pullulan consists of $\alpha(1,6)$-linked maltotriose $(\alpha(1,4)$-linked glucose), while laminarin is a $\beta(1,3)$ linked glucose polysaccharide. Pullulanase can function as a debranching enzyme of starch (Antranikian 1992); since starch is a common storage polysaccharide of phytoplankton (Bold 1985), high pullulanase activity might be expected in the water column. Sediments investigated to date with these substrates have in fact demonstrated high rates of hydrolysis for both pullulan and laminarin (Arnosti et al. 1994, Arnosti 1995, 1998).

A further contrast between previous measurements in sediments and this investigation of enzyme activity in the water column is that at all stations and locations, potential rates of xylan hydrolysis exceeded those of laminarin by factors of ca 2 to 10. The sole exceptions were the midbay and plume stations in January, when hydrolysis rates for both substrates were low, and the shelfbreak station in January. In sediments from other locations, however, potential rates of laminarin hydrolysis were consistently comparable to or more rapid than rates of xylan hydrolysis (Arnosti 1998, Arnosti \& Holmer 1999).

The contrasting behavior of the 4 substrates cannot be traced to monomer composition, since the component monomers of the polysaccharides used in this study are commonly detected in aquatic systems, including Delaware Bay. Glucose, mannose + xylose (co-eluting sugars), and fucose comprised 18,26 , and $18 \%$ of the dissolved $(0.2 \mu \mathrm{m}$ filtered) combined sugars, and 40,20 , and $9 \%$ of the total (unfiltered) combined sugars measured at Roosevelt Inlet in Delaware Bay (Borch \& Kirchman 1997). These same monosaccharides are important constituents of dissolved combined carbohydrates throughout the Bay. Borch (1998) found that the composition of dissolved combined carbohydrates in transects through Delaware Bay varied little, with glucose averaging $23 \pm 3.6 \%$, mannose + xylose as $22 \pm 2.0 \%$, and fucose as $16.6 \pm 0.6 \%$ of total neutral carbohy-
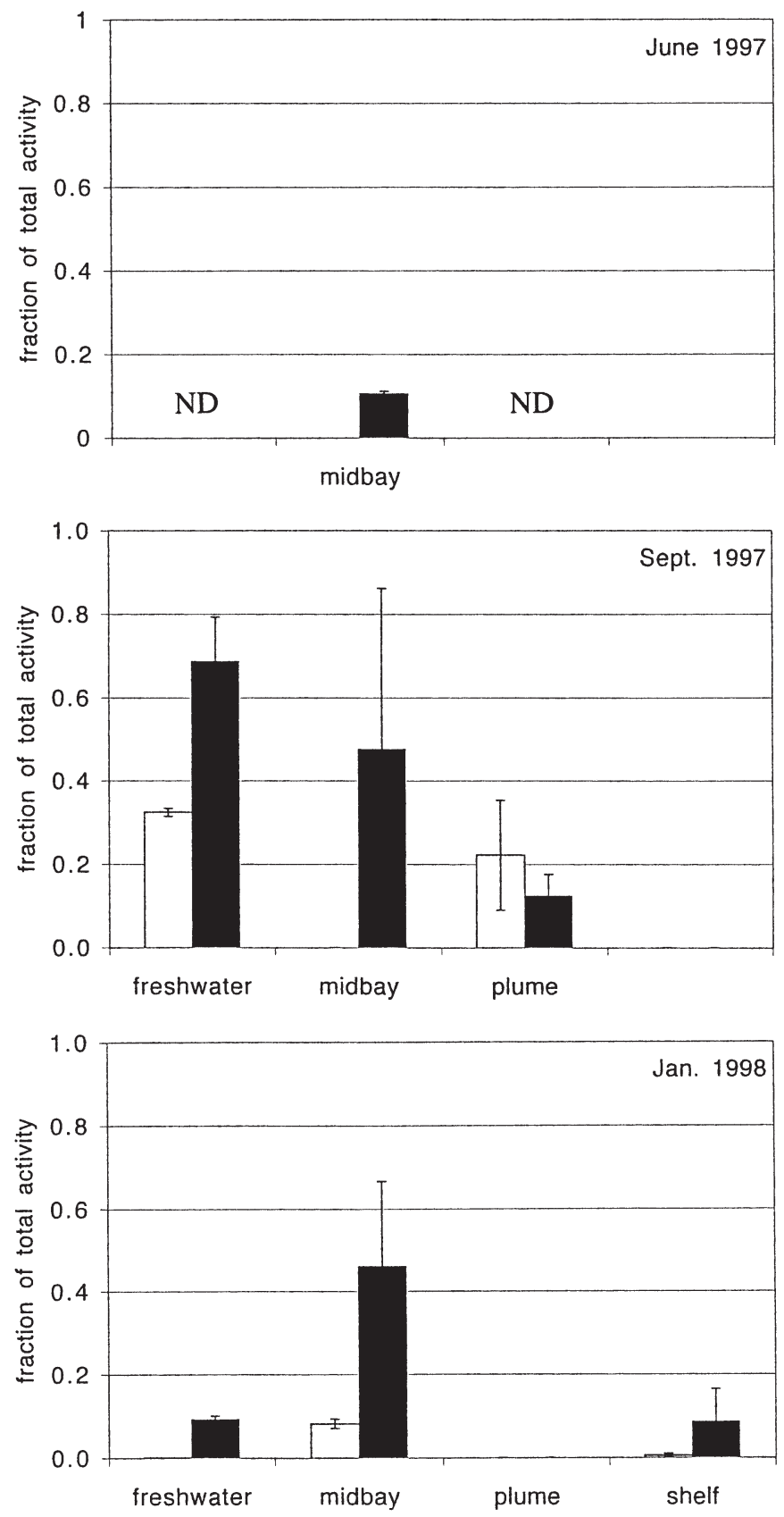

Fig. 5. Size-fractionation experiments ( $6 \mathrm{~d}$ incubations): xylan hydrolysis rates as a fraction of rates measured in unfiltered samples. White bars: 0.45 to $0.2 \mu \mathrm{m}$ fraction; black bars: free enzyme $(<0.2 \mu \mathrm{m})$ fraction. Error bars represent $\pm 1 \mathrm{SD}(\mathrm{n}=3)$. Note that fractionation experiments were carried out only at the midbay station in June

drates. The specific structures from which these carbohydrates are derived, however, remain unknown, since techniques to isolate and structurally characterize intact specific components of the HMW DOC pool remain to be developed. 


\section{Rates of polysaccharide turnover in Delaware River and Bay}

Despite the lack of information about the structure of the combined carbohydrate fraction of DOC, the potential hydrolysis rates measured in this study can be used to estimate boundaries on turnover times of this fraction of DOC. According to Borch (1998), dissolved combined neutral carbohydrates in the Delaware River and Bay exhibit little spatial or temporal variability, with total concentrations in the range of 0.7 to $1.8 \mu \mathrm{M}$. Borch \& Kirchman (1997) and Borch (1998) report combined glucose concentrations (i.e., glucose present as part of an oligo- or polymer, and not as the free monosaccharide) are on the order of $190 \mathrm{nM}$. Given laminarin potential hydrolysis rates of 2.4 to $40 \mathrm{nM}$ glucose $\mathrm{h}^{-1}$ (Fig. 3), the entire glucose pool, if occurring in a laminarin-like form, could be hydrolyzed to monosaccharides on timescales of 4.75 to $79 \mathrm{~h}$. If the combined glucose pool consisted of pullulan-like structures, however, effectively none of this pool would be hydrolyzed. Making a similar calculation, if all of this pool consisted of xylose in xylan-like structures, the combined mannose + xylose pool (co-eluting sugars) of $268 \mathrm{nM}$ (Borch \& Kirchman 1997) could potentially be hydrolyzed to monomers on timescales of 3.7 to $6.0 \mathrm{~h}$ (Fig. 3). If the combined fucose pool of $190 \mathrm{nM}$ is found in fucoidan-like structures, its turnover rate in almost all instances would essentially be zero.

These estimates of turnover times suggest an all-ornothing scenario: either a high molecular weight substrate is intrinsically labile and could be hydrolyzed and utilized extremely rapidly by the microbial community, or it is essentially unavailable even over relatively long timescales. The surprise in this case is that pullulan must be classified as relatively 'unavailable' for the planktonic community, although it hardly fits a conventional definition of a recalcitrant substrate. Furthermore, classification as 'unavailable' at least in this case applies only to the planktonic microbial community, since pullulan is rapidly hydrolyzed and remineralized by sedimentary microbes (Arnosti et al. 1994, Arnosti 1995, 1998).

The wide range of turnover rates estimated here may in fact effectively reflect the dynamics of the combined neutral carbohydrates in Delaware River and Bay. Borch (1998) demonstrated that a significant fraction of this pool is not degraded rapidly. He monitored concentrations of combined neutral carbohydrates (glucose, galactose+xylose, mannose, fucose, rhamnose, and arabinose) in $0.8 \mu \mathrm{m}$ filtered water samples collected from the Delaware River and Bay. Over the 37 to $138 \mathrm{~h}$ incubation periods, little change was typically observed in the concentrations of combined neutral carbohydrates. Only in one instance was degradation of combined glucose substantial; changes in concen- trations of the other combined carbohydrates were low to undetectable (Borch, 1998). These results suggest that at least a portion of the dissolved combined carbohydrate pool is intrinsically resistant to extracellular enzymatic hydrolysis and microbial utilization, perhaps because these combined carbohydrates are found in polysaccharides whose behavior is similar to pullulan and fucoidan.

A portion of the combined carbohydrate pool in Delaware Bay, however, may be turned over even more rapidly than laminarin or xylan. Borch (1998) also investigated decomposition of carbohydrates produced during a 2 d bloom initiated by adding nutrients to unfiltered water. In this experiment, a total of ca $20 \mu \mathrm{M}$ combined carbohydrates were produced during the bloom, and less than $4 \%$ of these carbohydrates remained $4 \mathrm{~d}$ after the bloom was terminated by placing it in the dark. Degradation of $19.2 \mu \mathrm{M}$ combined neutral carbohydrates over a $96 \mathrm{~h}$ timecourse yields an average hydrolysis rate of $200 \mathrm{nM} \mathrm{h}^{-1}$, a rate 3 to 4 times more rapid than the average xylan hydrolysis rates of 45 to $72 \mathrm{nM} \mathrm{h}^{-1}$ (Fig. 3).

An additional point to note is that the potential hydrolysis rates reported here for laminarin and xylan are generally higher than those typically reported for water column hydrolysis of the substrate analogs MUF $\alpha$ - and $\beta$-glucose (e.g. Hoppe 1983, Bochdansky et al. 1995, Karner \& Rassoulzadegan 1995, Martinez et al. 1996). The most likely reason is that small substrate analogs such as the MUF-dimers and HMW polysaccharides such as laminarin and xylan are hydrolyzed by entirely different classes of enzymes. While MUF-dimers are generally considered to be the target of enzymes which cleave monomeric units from the ends of a polymer (Marxen \& Witzel 1991, Warren 1996), the patterns of hydrolysis observed via gel permeation chromatography clearly indicate that the laminarin and xylan polymers were cleaved via the action of endo-acting exoenzymes, which hydrolyze polymers mid-chain. Martinez et al. (1996) in fact commented that potential hydrolysis rates of MUF $\alpha$ - and $\beta$-glucose substrates are typically are 'low' in comparison with other enzymes, and suggested that these MUF substrates may underestimate actual enzyme activities. Pantoja \& Lee (1999) have in fact found that hydrolysis rates measured via the fluorescent peptide analog leu-MCA were significantly lower than rates measured with longer peptides.

\section{Substrate specialization within microbial communities}

The different spatial and temporal patterns of laminarin and xylan hydrolysis (Fig. 3) suggest that different bacterial species or communities may be responsi- 
ble for hydrolyzing these 2 polysaccharides. This possibility is consistent with Martinez et al.'s (1996) investigation of a spectrum of enzyme activities among bacteria isolated from seawater samples. Using simple substrate analogs such MUF- $\alpha$ - and - $\beta$-glucose, they determined that the extent to which specific enzymes were expressed, as well as the types of enzymes expressed by each isolate, varied significantly. Enzyme expression in natural assemblages from seawater collected 4 times at the same location over the course of $7 \mathrm{~d}$ were also variable, although total bacterial abundance was relatively constant. Pinhassi et al. (1997) likewise found significant changes in planktonic bacterial community composition in a coastal environment over an annual cycle. Pinhassi et al. (1999) further investigated the population dynamics of bacteria in seawater mesocosms in response to substrate addition. A protein-enriched mesocosm demonstrated shifts in bacterial community composition concurrent with changes in enzyme activities, measured using a variety of substrate analogs. They suggested that the increased levels of enzyme activity measured in the protein-enriched mesocosm relative to the control mesocosm were a reflection of changing population composition, rather than simply due to induction of a suite of enzymes among a compositionally stable population. A recent study has in fact shown that extensive changes in microbial community composition (monitored via denaturing gradient gel electrophoresis) and associated increases in potential enzyme activities were closely correlated with the colonization and decay of a plytoplankton bloom induced in a mesocosm (Riemann et al. 2000). The spatial and temporal changes in potential enzyme activities measured in this study might therefore reflect seasonal and siterelated changes in the population densities or levels of activity of the organisms which produce laminarinase and xylanase enzymes. Such changes might be a response to factors such as spatial and/or seasonal shifts in the phytoplankton populations in the Delaware River and Bay.

The temporal and spatial differences in the contributions of free enzyme fractions to laminarin and xylan hydrolysis (Figs. 4 \& 5) additionally supported the hypothesis that distinct members of the microbial community produced the enzymes which hydrolyze these substrates, or that there was some form of selective production of free enzymes. Especially in September, free enzymes (the $<0.2 \mu \mathrm{m}$ fraction) contributed most or all of the enzyme activity at the freshwater and midbay stations for xylan, and at the midbay and plume stations for laminarin.

Significant temporal and spatial variability in activity of free enzymes is consistent with a study of Mediterranean waters, in which the contribution of the
$<0.1 \mu \mathrm{m}$ size fraction to hydrolysis of the substrate analogs MUF- $\alpha$ - and - $\beta$-glucose varied between 0 and $100 \%$ on $24 \mathrm{~h}$ timescales (Karner \& Rassoulzadegan 1995). Pantoja \& Lee (1999) likewise found that the effects of filtration on peptide hydrolysis rates in coastal seawater varied by substrate. In one case, hydrolysis of tetrapeptides and tripeptides was equally rapid in filtered $(0.2 \mu \mathrm{m})$ and unfiltered seawater, while hydrolysis of a dipeptide was minimal in the filtered seawater. A further comparison showed site- as well as filtration-related differences in hydrolysis rates, with a greater proportion of free enzyme activity $(<0.2 \mu \mathrm{m})$ found at the more organic-rich seawater site. They hypothesized that more free enzymes might be released in the presence of higher substrate concentrations. In pure cultures of bacteria, production of free enzymes has in fact been found to be a function of growth phase and substrate concentration (e.g. Antranikian et al. 1987). Enhanced free enzyme production has also been observed as a response to starvation (Albertson et al. 1990). Free enzymes could also be generated by a variety of mechanisms, potentially including viral lysis (Karner \& Rassoulzadegan 1995) and zooplankton grazing (Bochdansky et al. 1995).

The variable and at times very high contributions of the free enzyme fractions to total activity could also contribute to a general lack of coherence between broad measures of total microbial populations and the activities of specific enzymes. Potential hydrolysis rates were compared to large-scale chemical and microbial parameters from the river-bay-plume stations for June and September 1997 (Sharp pers. comm.). There were no statistical correlations with DOC, which is conservative along the estuarine transect, and shows no seasonal variation (Sharp et al. 1982). The temporal and spatial variations in laminarin and xylan hydrolysis rates were also independent of bacterial abundance and metabolic activity (data not shown). Bacterial abundance changes from station to station in the river-bay, and shows significant seasonable variations (Sharp et al. 1986, Hoch \& Kirchman 1993, Sharp pers. comm.). Since the highest potential hydrolysis rates for both substrates were measured in September and the lowest rates in January (Fig. 3), these highs and lows could potentially be related to a variety of factors, including temperature (Table 1), as well as seasonal highs and lows in total bacterial abundance typically observed in this environment in August and January (Hoch \& Kirchman 1993). The fact that rates of laminarin and xylan hydrolysis measured at the freshwater station in January are comparable to rates measured during June, however, demonstrates that neither temperature nor bacterial abundance alone is likely to be the primary factor affecting potential hydrolysis rates. 
Variable or weak correlations between total bacterial numbers or bacterial production and enzyme activities have been noted previously (e.g. Mayer 1989, Boetius et al. 1996, Murrell et al. 1999). A fundamental difficulty with seeking such correlations is the probability that only a subset of the microbial population produces the enzymes whose activities are measured, although a wider range of bacteria may metabolize the resultant hydrolysis products. Studies of rumen bacteria have in fact demonstrated this pattern of substrate utilization (Cotta 1992). Cottrell \& Kirchman (2000) have recently used microautoradiography and fluorescent in situ hybridization (FISH) to demonstrate that the contributions of different phylogenetic groups of bacteria to substrate utilization in marine systems is not a simple function of their relative abundance. They found in particular that the Cytophaga-flavobacteria were prominent among organisms using HMW substrates (including protein), although their uptake of the corresponding LMW substrates (amino acids) was disproportionately low. These results, as well as the apparent resistance of relatively simple polysaccharides such as fucoidan and pullulan to extracellular enzymatic hydrolysis in the water column, starkly illustrate our limited knowledge of the nature and expression of extracellular enzymes among aquatic microbes. Ultimately, the use of naturally produced macromolecules will be necessary for more complete understanding of extracellular hydrolysis processes (see Warren 1996); the fluorescently labeled polysaccharides used here represent a step in this direction.

Acknowledgements. Thanks to the captain and crew of the RV 'Cape Henlopen', and to D. Kirchman and J. Sharp for providing ship space as well as data on microbial activity and nutrient distribution. D. Albert, M. Alperin, N. Blair, and B. B. Jørgensen assisted in data interpretation and reviewed drafts of the manuscript. Two anonymous reviewers provided additional helpful comments. We are very grateful to a third reviewer who pointed out inconsistencies in previous data calculations. Funding was provided to C.A. by the Petroleum Research Fund, the EPA STAR program, and NSF. S.K. received an NSF Graduate Research Fellowship.

\section{LITERATURE CITED}

Albertson NH, Nystrom T, Kjelleberg S (1990) Exoprotease activity of two marine bacteria during starvation. Appl Environ Microbiol 56:218-223

Aluwihare LI, Repeta DJ, Chen RF (1997) A major biopolymeric component to dissolved organic carbon in surface sea water. Nature 387:166-169

Antranikian G (1992) Microbial degradation of starch. In: Winkelman G (ed) Microbial degradation of natural products. Verlag Chemie, New York, p 27-56

Antranikian G, Herzberg C, Gottschalk G (1987) Production of thermostable $\alpha$-amylase, pullulanase, and $\alpha$-glucosidase in continuous culture by a new Clostridium isolate.
Appl Environ Microbiol 53(7):1668-1673

Arnosti C (1995) Measurement of depth- and site-related differences in polysaccharide hydrolysis rates in marine sediments. Geochim Cosmochim Acta 59:4247-4257

Arnosti C (1996) A new method for measuring polysaccharide hydrolysis rates in marine environments. Org Geochem 25:105-115

Arnosti C (1998) Rapid potential hydrolysis rates of extracellular enzymes in Arctic sediments. Limnol Oceanogr 43: 315-324

Arnosti C (2000) Substrate specificity in polysaccharide hydrolysis: contrasts between bottom water and sediments. Limnol Oceanogr 45:1112-1119

Arnosti C, Holmer M (1999) Carbohydrate dynamics and contributions to the carbon budget of an organic-rich coastal sediment. Geochim Cosmochim Acta 63:393-493

Arnosti C, Repeta DJ, Blough NV (1994) Rapid bacterial degradation of polysaccharides in anoxic marine systems. Geochim Cosmochim Acta 58:2639-2652

Azam F (1998) Microbial control of oceanic carbon flux: the plot thickens. Science 280:694-696

Benner R, Pakulski, JD, McCarthy M, Hedges JI, Hatcher PG (1992) Bulk chemical characteristics of dissolved organic matter in the ocean. Science 255:1561-1564

Biersmith A, Benner R (1998) Carbohydrates in phytoplankton and freshly produced dissolved organic matter. Mar Chem 63:131-144

Bochdansky AB, Puskaric S, Herndl GJ (1995) Influence of zooplankton grazing on free dissolved enzymes in the sea. Mar Ecol Prog Ser 121:53-63

Boetius A, Scheibe S, Tselepides A, Thiel H (1996) Microbial biomass and activities in deep-sea sediments of the Eastern Mediterrranean: trenches are benthic hotspots. DeepSea Res I 43:1439-1460

Bold HC (1985) Algae. Prentice Hall, Englewood Cliffs, NJ

Borch NH (1998) Turnover of high molecular weight organic matter in the ocean. PhD thesis, Univ. Delaware, Newark

Borch NH, Kirchman DL (1997) Concentration and composition of dissolved combined neutral sugars (polysaccharides) in seawater determined by HPLC-PAD. Mar Chem 57:85-95

Boschker HTS, Bertilsson SA, Dekkers EMJ, Cappenberg TE (1995) An inhibitor-based method to measure initial decomposition of naturally occurring polysaccharides in sediments. Appl Environ Microbiol 61:2186-2192

Brown SH, Costantino HR, Kelly RM (1990) Characterization of amylolytic enzyme activities associated with the hyperthermophilic archaebacterium Pyrococcus furiosus. Appl Environ Microbiol 56(7):1985-1991

Chappell KR, Goulder R (1995) A between river comparison of extracellular-enzyme activity. Microb Ecol 29:1-17

Cifuentes LA, Sharp JH, Fogel ML (1988) Stable carbon and nitrogen isotope biogeochemistry in the Delaware estuary. Limnol Oceanogr 33:1102-1115

Cotta MA (1992) Interaction of ruminal bacteria in the production and utilization of maltooligosaccharides from starch. Appl Environ Microbiol 58:48-54

Cottrell MT, Kirchman DL (2000) Natural assemblages of marine proteobacteria and members of the CytophagaFlavobacter cluster consuming low- and high-molecularweight dissolved organic matter. Appl Environ Microbiol 66:1692-1697

Davis CL (1992) Production of laiminarinase and alginase by marine bacteria after starvation. FEMS Microbiol Ecol 86: 349-356

Decad GM, Nikaido H (1976) Outer membrane of gram-negative bacteria XII Molecular-sieving function of cell wall. 
J Bacteriol 128:325-336

Fry B, Hopkinson CS Jr, Nolin A, Norrman B, Zweifel UL (1996) Long-term decomposition of DOC from experimental diatom blooms. Limnol Oceanogr 41:1344-1347

Glabe CG, Harty PK, Rosen SD (1983) Preparation and properties of fluorescent polysaccharides Anal Biochem 130: $287-299$

Hedges JI (1992) Global biogeochemical cycles: progress and problems. Mar Chem 39:67-93

Hoch MP, Kirchman DL (1993) Seasonal and interannual variability in bacterial production and biomass in a temperate estuary. Mar Ecol Prog Ser 98:283-295

Hoppe HG (1983) Significance of exoenzymatic activities in the ecology of brackish water: measurements by means of methylumbelliferyl-substrates. Mar Ecol Prog Ser 11: 299-308

Karner M, Rassoulzadegan F (1995) Extracellular enzyme activity: indications for high short-term variability in a coastal marine ecosystem. Microb Ecol 30:143-156

Ketchum BH (1952) The distribution of salinity in the estuary of the Delaware River. Woods Hole Oceanographic Institution, Woods Hole, MA

Kirchman DL, Hoch MP (1988) Bacterial production in the Delaware Bay estuary estimated from thymidine and leucine incorporation rates. Mar Ecol Prog Ser 45:169-178

Martinez J, Azam F (1993) Periplasmic aminopeptidase and alkaline phosphatase activities in a marine bacterium: implications for substrate processing in the sea. Mar Ecol Prog Ser 92:89-97

Martinez J, Smith DC, Steward GF, Azam F (1996) Variability in ectohydrolytic enzyme activities of pelagic marine bacteria and its significance for substrate processing in the sea. Aquat Microb Ecol 10:223-230

Marxen J, Witzel KP (1991) Significance of extracellular enzymes for organic matter degradation and nutrient regeneration in small streams. In: Chróst RJ (ed) Microbial enzymes in aquatic environments. Springer-Verlag, New York, p 270-285

Mayer LM (1989) Extracellular proteolytic enzyme activity in sediments of an intertidal mudflat. Limnol Oceanogr 34: 973-981

Murrell MC, Hollibaugh JT, Silver MW, Wong PS (1999) Bacterioplankton dynamics in northern San Francisco Bay: role of particle assocition and seasonal freshwater flow.

Editorial responsibility: Patricia Glibert,

Cambridge, Maryland, USA
Limnol Oceanogr 44:295-308

Norrman B, Zweifel UL, Hopkinson CS Jr, Fry B (1995) Production and utilization of dissolved organic carbon during an experimental diatom bloom. Limnol Oceanogr 40: 898-907

Pantoja S, Lee C (1999) Peptide decomposition by extracellular hydrolysis in coastal seawater and salt marsh sediment. Mar Chem 63:273-291

Pinhassi J, Zweifel UL, Hagström Å (1997) Dominant marine bacterioplankton species found among colony-forming bacteria. Appl Environ Microbiol 63:3359-3366

Pinhassi J, Azam F, Hemphala J, Long RA, Martinez J, Zweifel UL, Hagström $\AA$ (1999) Coupling between bacterioplankton species composition, population dynamics, and organic matter degradation. Aquat Microb Ecol 17: $13-26$

Riemann L, Steward GF, Azam F (2000) Dynamics of bacterial community composition and activity during a mesocosm diatom bloom. Appl Environ Microbiol 66:578-587

Sakugawa H, Handa N (1985) Chemical studies on dissolved carbohydrates in the water samples collected from the North Pacific and Bering Sea. Oceanol Acta 8:185-196

Sakugawa H, Handa N, Ohta K (1985) Isolation and characterization of low molecular weight carbohydrates dissolved in seawater. Mar Chem 17:341-362

Sharp JH, Cifuentes LA, Coffin RB, Pennock JR (1986) The influence of river variability on the circulation, chemistry, and microbiology of the Delaware estuary. Estuaries 9: 261-269

Sharp JH, Culberson CH, Church TM (1982) The chemistry of the Delaware estuary. General considerations. Limnol Oceanogr 27:1015-1028

Smith DC, Simon M, Alldredge AL, Azam F (1992) Intense hydrolytic enzyme activity on marine aggregates and implications for rapid particle dissolution. Nature 359: 139-142

Wainwright M (1981) Assay and properties of alginate lyase and 1,3- $\beta$-glucanase in intertidal sands. Plant Soil 59(1): 83-89

Warren RAJ (1996) Microbial hydrolysis of polysaccharides. Annu Rev Microbiol 50:183-212

Williams PM, Druffel ERM (1987) Radiocarbon in dissolved organic matter in the central North Pacific Ocean. Nature 330:246-248

Submitted: May 10, 2000; Accepted: May 1, 2001

Proofs received from author(s): July 4, 2001 